\title{
RESPONSE OF DWPF THERMAL FLOWMETERS TO COMPOSITION CHANGE - EFFECT ON 02 DETERMINATION IN SALT PROCESS CELL (U)
}

by R. A. Jacobs

Westinghouse Savannah River Company

WSRC-TR- $-92-069$

Savannah River Site

Aiken, South Carolina 29808

DE93 008508

Other Authors:

This paper was prepared in connection with work done under Contract No. DE-AC09-89SR18035 with the U. S. Department of Energy. By acceptance of this paper, the publisher and/or recipient acknowledges the U. S. Government's rit ${ }^{2+}+$ to retain a nonexclusive, royalty-free license in and to any copyright covering this paper, along with the rigit to reproduce and to authorize others to reproduce all or part of the copyrighted paper. 


\section{DISCLAIMER}

This report was prepared as an account of work sponsored by an agency of the United States Government. Neither the United States Government nor any agency thereof, nor any of their employees, makes any warranty, express or implied, or assumes any legal liability or responsibility for the accuracy, completeness, or usefulness of any information, apparatus, product, or process disclosed, or represents that its use would not infringe privately owned rights. Reference herein to any specific commercial produch, process, or service by trade name, trademark, manufacturer, or otherwise does not necessarily constitute or imply its endorsement, recommendation, or favoring by the United States Government or any agency thereof. The views and opinions of authors expressed herein do not necessarily state or reflect those of the United States Government or any agency thereof.

This report has been reproduced directly from the best available copy.

Available to DOE and DOE contractors from the Office of Scientific and Technical Information, P.O. Box 62, Oak Ridge, TN 37831; prices available from (615) 576-8401, FTS 626-8401.

Available to the public from the National Technical Information Service, U.S. Department of Commerce, 5285 Port Royal Rd, Springfield, VA 2:2iúl. 


\title{
INTER-OFFICE MEMORANDUM
}

\author{
WSRC-TR-92-0069 \\ Keywords: DWPE, benzene, \\ Salt Process Cell, \\ precipitate nydrolysis, \\ atr inleakage
}

Retention period: Permanent

$$
\begin{aligned}
& \text { cc: J. T. Carter, 704-1T } \\
& \text { I. E. Landon, 704-T } \\
& \text { M. A. Baich, 704-T } \\
& \text { D. P. Lambert, 704-1T } \\
& \text { J. C. Marek, } 704-T \\
& \text { J. A. Ritter, 704-1T } \\
& \text { H. B. Shab, 704-1T } \\
& \text { S. R. Young, 704-1T } \\
& \text { J. R. Zamecn1k, 704-1T } \\
& \text { SRI Records (4) } \\
& \text { Eobruary 3, } 1992
\end{aligned}
$$

TO:

EROM :

E. W. HOLTZSCHEITER, 773-A

R. A. JACOBS, 704-T

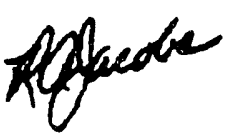

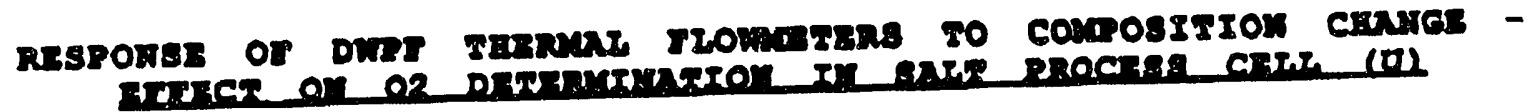

\section{sumney and conchuntoms}

Thermal flowmeters (more accurately described as bot wire anemometers) have been Inatalled in the salt process Cell (SRC) to measure in-cell process flows. In conjunction with purge flow meters in the third level corridor, it was initially planned to use these meters to estimate the alr inleakage and 02 concentration in each vessel system. The overall balance would be conftrmed using a thermal flowmeter and 02 analyzer located at the exit of the salt Cell vent Condenser (SCVC).

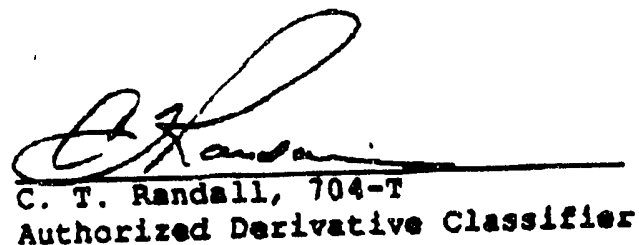


When this methodology was looked at more closely to assess the accuracy of tire estimates, tise efrect of changliy vapor compositions on indicated us actual flow was considered. In many vapor/gas flowmeters, correcting for composition 1s simple and even "rough" estimates of gas composition are sufficient to yleld adequate results. However, upon investigating the effect of composition on thermal flow meters, it was concluded that determining a priorl correction factors is a very complicated process requiring falrly preclse knowledge of the vapor composition and the meter characteristics. In fact, one thermal flow meter manufacturer (Kurz) maintains that corrections can only be determined by calibration with the actual gas/vapor compositions. Other types of flow meters lorifice/Ap, vortex shedding, turbine, etc.l were considered and refected, principaliy due to the large pressure drop occuring at the perlodic high flow rates assoclated with the HAN process.

\section{It is recommended that DKPE}

- estimate alr tnleakage using a test procedure simłlar to one beling developed in the Precipitate Hydrolysis Experimental Eacility (PHEF) $\dagger$ which circumvents the correction problem by in situ calibration, and

- develop a profile whtch charactertzes atr inleakage as a function of $\Delta P$ to be used in confunction with the inleakage test procedure.

The recommended test procedure has some distinct advantages over the simple material balance approach. More detalled information on the characteristics of thermal flow meters, the recommended afr inleakage test procedure, and the inleakage proflle are discussed below.

\section{Dtearneton}

\section{Background}

The SPC contains four vegsel (diagram attached) systems whlch are mainicalned at a vacuum relative to the cell and which all vent through the scre:

- the Precipitate Reactor Feed Tank (PRFT),

- the Precipltate-Reactor (PR) and $P R$ Condenser/Decanter (PRCD),

- the Organic Evaporator (OE) and OE Condenser/Decanter (OECD), and

- the OE Condensate Tank (OECI).

t This procedure ts being developed by $K$. B. Shah and $S$. R. Young and will be document in a future report. 


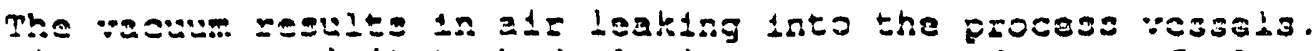
since tha precipitate hydrolysis process produces a flit (benzene), the vessels in the SPC have been designed to minimize air inleakage and each of the vessel systems has its own inert purge flow addition meter and In-process thermal llow meter located on the vent of the vessel system. Also, there is a flow meter and 02 analyzer on the commor vent ine at the exit of the SCVC.

While the common 02 analyzer can assure that sufflctent inert is added for the total air inleakage, it cannot guarantee that each vessel system is adeguately purged. If it were assumed that all the a1s inleakage (as determined at the SCVC) were into one system and sufficlent inert added to each system for that leakage, then excessive benzene emissions would result. To assure that each system is safe and to minimize benzene emissions, it was intended to estimate the air inleakage on each system by doing a simple marerial balance using the purge and inprocess flow meters.

\section{Thermal Flownoters}

Thermal flow meters are hot wire anemometers and work on the fundamental principle of measuring the heat loss from a hot wire to the flowling gas. For a given meter and gas composition, the heat loss is measured by the current in the wire and is a noninear function of velocity only. However if the composition of the gas varies, the velocity of the gas as a function of wire current is (1)

$$
u=\frac{\left(\frac{I^{2} R_{w}}{\Delta t}\right)^{2} \cdot 0.76 k_{f}\left(\frac{I^{2} R_{w}}{\Delta t}\right)\left[N_{P r}\right]_{f}^{0.2} K_{1}}{\rho_{f} K_{2} \sqrt[3]{\left(C_{p}\right) f^{2} k_{f} / / \mu f}}
$$

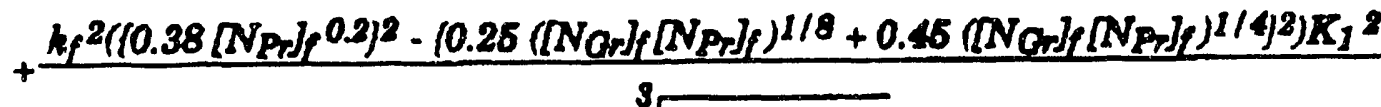

$$
\begin{aligned}
& \rho_{f} K_{2} \sqrt[3]{\left(C_{p}\right) r^{2} k_{f}^{4} / 4 p}
\end{aligned}
$$

where

$$
\begin{aligned}
& C_{p} \quad-\text { specific heat, B.t.u/lb- }{ }^{\circ} \\
& D \text { - diametor, it } \\
& 8 \text { - acceleration due to gravity, ft/hr' } \\
& \text { I = electrical current flowing through wire, mamp. } \\
& h \quad=\text { thermal conductivity, B.t.u./hr-ft }-^{\circ} \mathrm{E} \\
& K_{1}, K_{2} \text { - constants } \\
& N_{G r}=\text { Grashof number, }\left(g \rho^{2} D^{3} \beta^{2} \Delta t / \mu^{2}\right)
\end{aligned}
$$


E. W. HOLTZSCHEITER

WSRC-TR-92-0069

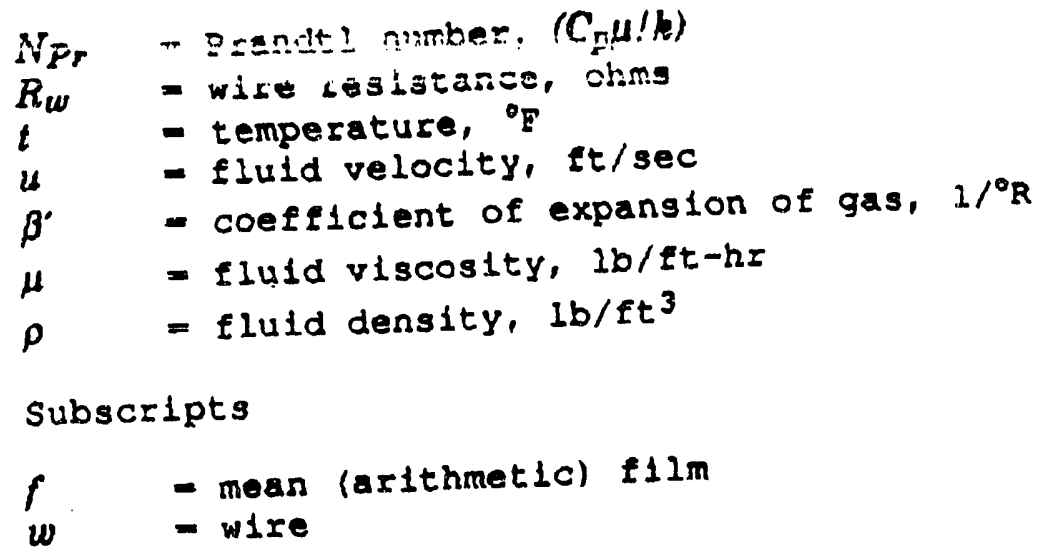

In addition to this complex correlation, calculations are further complicated by the fact that the thermal conductivity and viscosity of gas mixtures are in themseles. (2) A calculational functions of the pure component propert 1 and expected PHEF and method using information from reference cop the calculations are DWPE compositions was deve

In conversations with Mr. Greg Ochs, techntcal representative of Fluidic Components Incorporated (ECI), he Indlcated that actual vs indicated readings do, in fact, vary widely with gas and complicated functions of density, thermal composition and acosity, heat capacity, and compressibility at conductivity, viscoslty, hat developed a proprietary capability elevated pressures. ECI has devern known compositions. A to estimate correction factors from known comparison shows:

\begin{tabular}{|c|c|c|c|c|}
\hline & Gas C & astition & colume er & ten \\
\hline & 1 & 2 & -3 & 4 \\
\hline $\begin{array}{c}\text { Component : } \\
\text { A1x } \\
\text { CO2 } \\
\text { N2 } \\
\text { N2O } \\
\text { Benzene }\end{array}$ & $\begin{array}{l}0.05 \\
0 \\
0.81 \\
0.07 \\
0.07\end{array}$ & $\begin{array}{l}0.05 \\
0 \\
0.86 \\
0.07 \\
0.02\end{array}$ & $\begin{array}{l}0.286 \\
0.714 \\
0 \\
0 \\
0\end{array}$ & $\begin{array}{l}0.025 \\
0.815 \\
0 \\
0.10 \\
0.06\end{array}$ \\
\hline $\begin{array}{l}\text { Eactor per FCI: } \\
\text { Factor by author: }\end{array}$ & $\begin{array}{l}1.142^{\star} \\
1.182^{\star}\end{array}$ & $\begin{array}{l}1.078^{\star} \\
1.074^{\star}\end{array}$ & $\begin{array}{l}0.923^{\text {\#* }} \\
0.827^{\text {** }}\end{array}$ & $\begin{array}{l}1.030^{* \star} \\
1.006^{\star \star}\end{array}$ \\
\hline
\end{tabular}

* Meter calibrated for air

* Meter calibrated for CO2

The estimates for a N2 purged system (mixtures 1 and 2) are quite close while those for $\mathrm{CO} 2$ dominated miditures ( 3 and 4$)$ are in the close while those for CO2 dominated midtures further discussions
with $\mathrm{Mr}$. Ochs did not elucldate the reasons for the larger 
differences with $\mathrm{CO}$. PHEE date was also analyzed and compared to correclioj factors estimated by the author whth atmilar results.

\section{Teet Procedure to Determine Air Inleakage}

After considerable effort trying to develop a method for correcting actual vs indicated readings, the concept of a test procedure which completely circumvents the composition induced errors of the thermal flowmeter was formed (actually, it is a variation of a test procedure suggested by Mike sodaro, formerly of DNPE-Technical). The principal 1s: callbrate the meter in place for the flowing gas by changing the volumetric flow by a known amount. This is followed by obtalining a reading at a different air inleakage rate caused by changing the process operating pressure. An example of such a test is:

- The test starts at quiescent conditions in the process vessels; the flow through the in-process (thermal) meter is essentially the sum of the purge flow plus the atr inleakage at the current process operating pressure. Assume the $\mathrm{CO} 2$ purge is $2.0 \mathrm{scfm}\left(0^{\circ} \mathrm{C}+14.7 \mathrm{ps} 1 \mathrm{a}\right)=14.71$ lbs/hr and the ir inleakage $1 \mathrm{~s} 0.5 \mathrm{scfm}=2.42 \mathrm{lbs} / \mathrm{hr}$.: therefore, the 02 concentration is $4.2 \%$. A1so, assume the thermal flowmeter reads (Incorrectiy) $18.8 \mathrm{lbs} / \mathrm{hr}$. and the process pressure is -3.5 "wC relative to the cell.

- The next step 13 to increase the co2 purge rate, say to 4.0 scfm. As soon as the process pressure settles out at $-3.5^{\prime \prime}$ w, read the thermal flow meter and limnediately return the purge flow to the orlginal setting. (Woty: ald etepe not at the oxiglond, cusereent coaditione noed to be done as oulckly as poselble so thet the compostion/density of the ge loning tbrough tbe noter does not change.) Say the thormal meter reading at the increased purge rate is $37.2 \mathrm{lbs} / \mathrm{hr}$. If the process vessel temperature $1835^{\circ} \mathrm{C}$, this step shows that the meter response to a change in flow is

$$
\frac{(37.2-18.8) 1 \mathrm{bs} / \mathrm{hr}}{(4.0-2.0) 1 t^{3} / \mathrm{mln} * \frac{308^{\circ} \mathrm{K}}{273^{\circ} \mathrm{K}}}=8.155 \mathrm{lbs} / \mathrm{hr} \text { per acfm }
$$

- The third step is to change the alr inleakage by changing the process pressure. Assume the meter stili reads 18.8 lbs/hr at -3.5 "wc and reads $22.8 \mathrm{lbs} / \mathrm{hr}$ at -12.1 "wc. From the previous step, the change in flow at the meter is

$$
\frac{(22.8-18.8) \mathrm{lbs} / \mathrm{hr}}{8.155 \mathrm{lbs} / \mathrm{hr} \text { per acfm }}=0.4905 \mathrm{ft}^{3} / \mathrm{min}
$$


- The Inal stef is to calculate the initfal ais inleakage Ex=m tha pravious result. Assuming turbulent fiow that is, flow $-\sqrt{\Delta P}$, then it can be shown that the inftlal atr leakage is

$$
\frac{0.4905 \mathrm{ft}^{3} / \mathrm{mln}}{\sqrt{\frac{12.1}{3.5}}-1}=0.5708 \mathrm{ft}^{3} / \mathrm{min}
$$

wors: The flow may not be turbulent, see discussion of inleakage proflle.

Correcting back to standard conditions, the calculated quiescent air leakage is

$$
0.5708 * \frac{273^{\circ} \mathrm{K}}{308^{\circ} \mathrm{K}}=0.506 \operatorname{sctm}
$$

and the calculated 02 concentration is

$$
\frac{21 * 0.506 \mathrm{scfm}}{0.306 \mathrm{scfm}+2.0 \mathrm{scfm}}=4.24 \cdot 02
$$

\section{Test Procadure Adrantages}

Thls test procedure has two distinct advantages over the material balance approach (that is, using the llow meter readings at quiescent conditions):

- the results w1ll be correct even if the thermal flow meter is out of callbration, and

- presence of other components (such as benzene) are automatically compensated for. Thus, they are not counted as alr which would require additlonal, unnecessary purge flows resulting in increased benzene emisolons.

\section{Inlaakage prost10}

The above example assumes the flow through the points of leakage is turbulent. However, for low $\Delta P^{\prime}$ s and for flows through slits, the flow could very well be laminar; in which case flow is $\Delta$. The exponent for the $\Delta P$ term could range anywhere from 1.0 (laminar) to 0.5 (turbulent). It will be necessary to characterize the alr inleakage as a function of $\Delta p$ to use in the final calculation step. probably the simplest way to establish this information would be to gather:data on flow through the various thermal flow meters over a range of $\Delta P^{\prime} s$ with no inert flow to the vessels; that 1s, there would be no change in 
composition at the flow meters during the course of the characterization. The inleakage profile should probably be determined any time equipment in the SPC has been disessembled - . bulk alf leakage will have to be checked after each disassembly anyway.

\section{References}

1. W. T. Wasan, R. M. Davis, and C. R. Wilke, MEASUREMENT OF THE VELOCITY OF GASES WITH VARIABLE FLUID RRORERTIES, AIChE Journal, Vol. 14, No.2, March 1968, 1986.

2. R. C. Reid, J. M. Prausnitz, and T. K. Sherwood, THE PROPERTIES OF GASES AND LIQUIDS, MCGIAW HIIl, 1977.

3. R. A, Jacobs, THERMAL FLOWMETER CALCULATIONS, SRL-PTD-920007, February 3, 1992. 


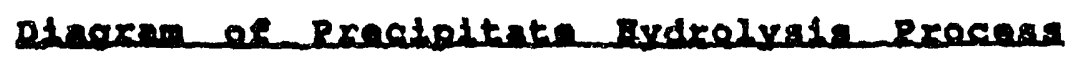

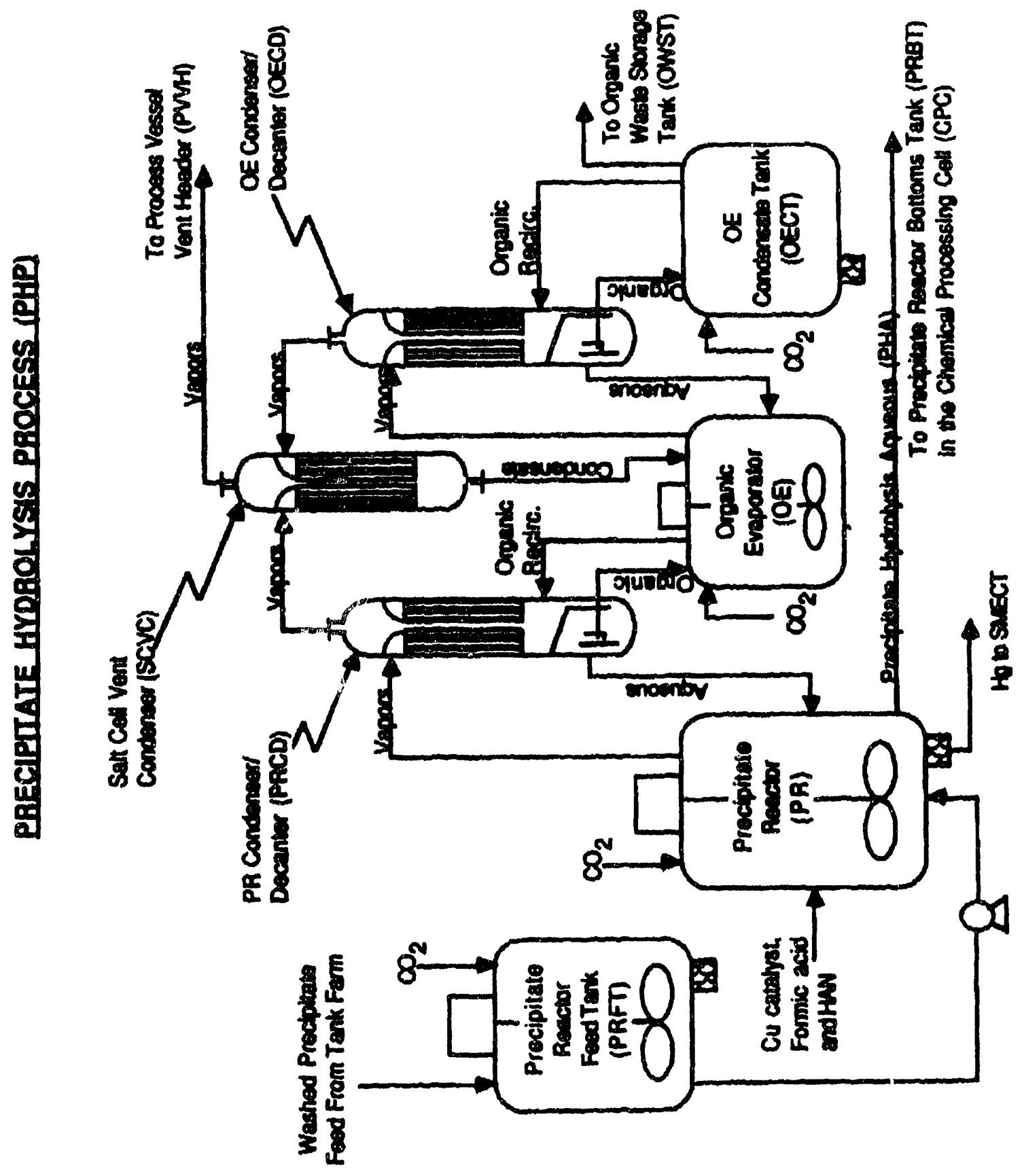



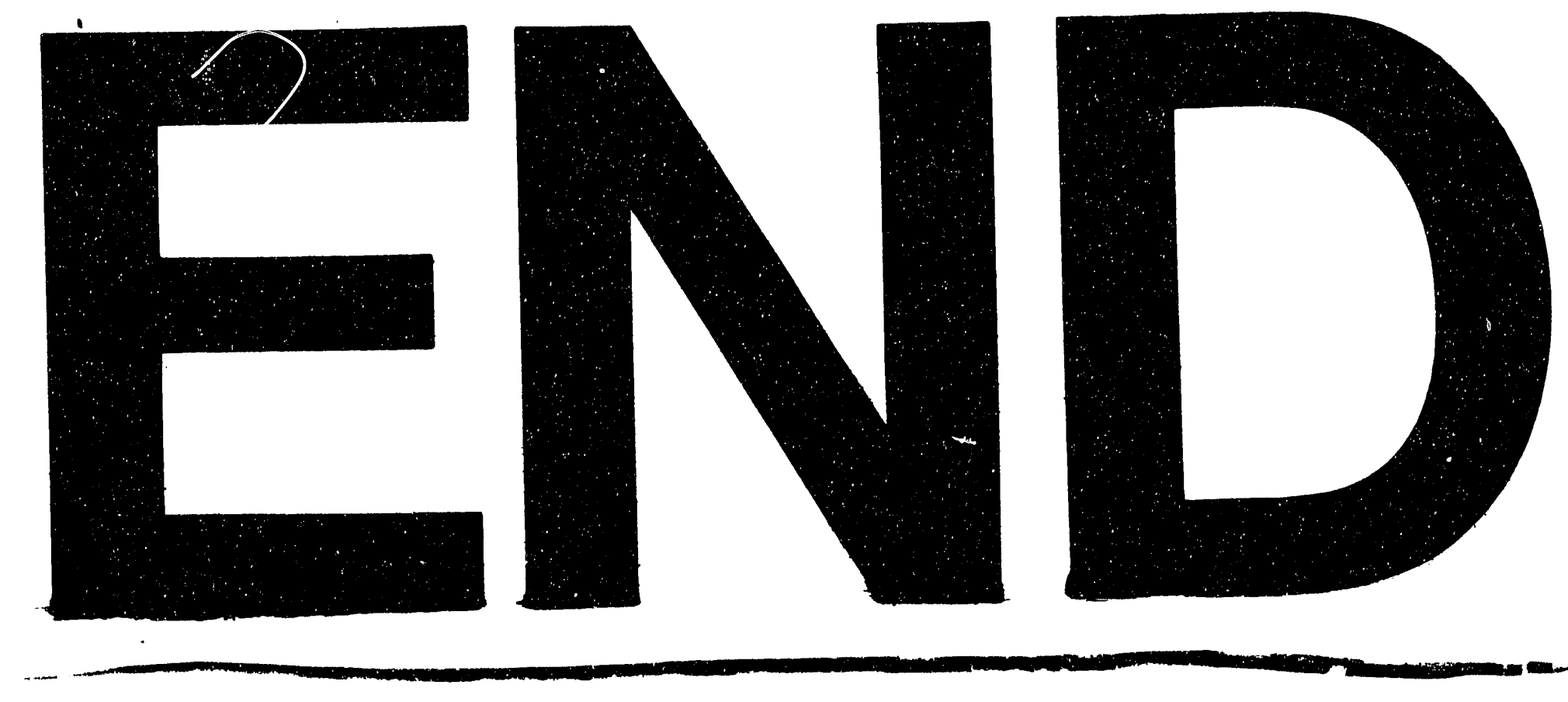

|
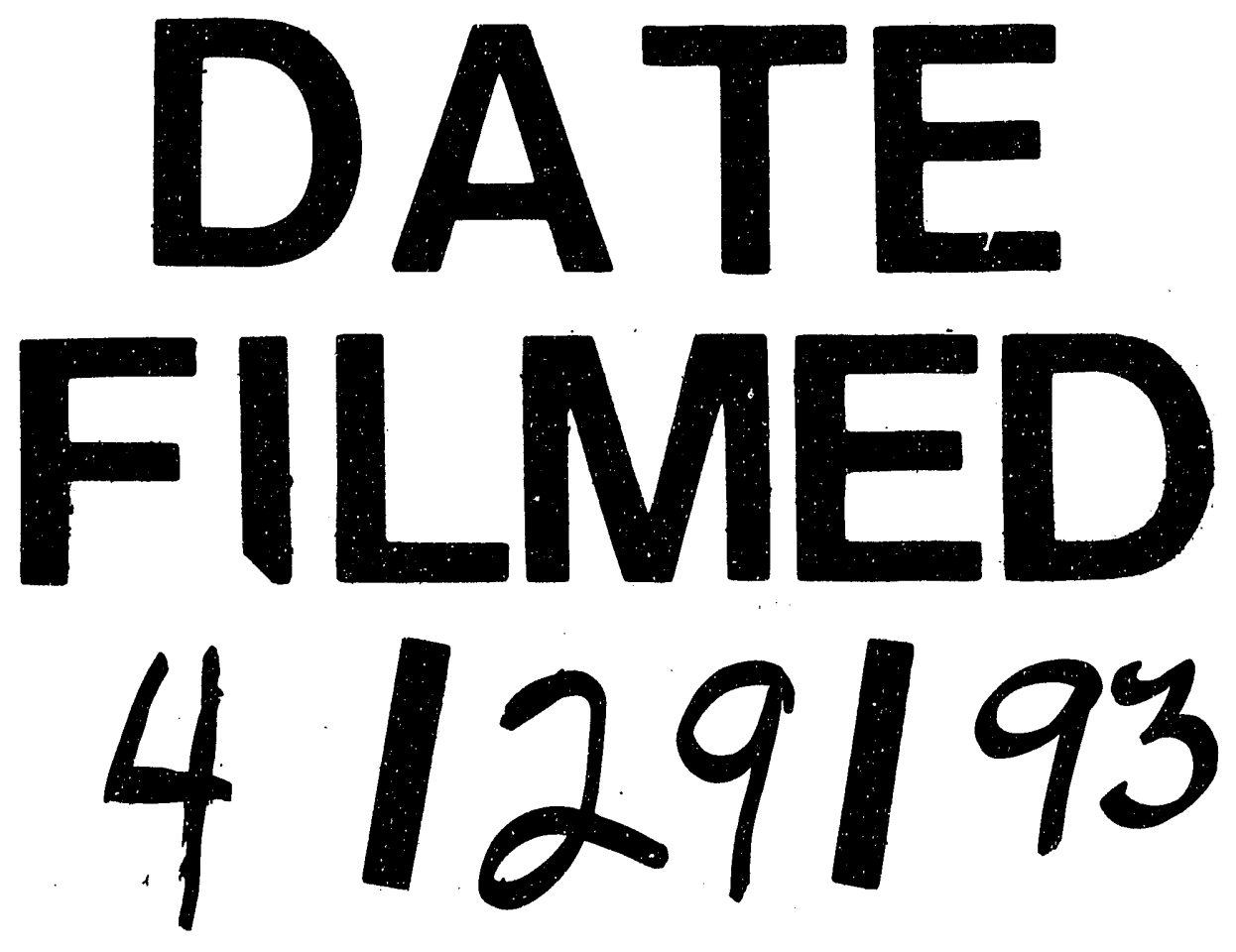
